\title{
PENGARUH IKLANSMARTPHONE TERHADAP PERILAKU BRAND SWITCHING KONSUMEN BAYUNG LENCIR MUSI BANYUASIN
}

\author{
Ade Nia Suryani \\ Sekolah Tinggi Ilmu Ekonomi Rahmaniyah Sekayu \\ Email: adenia_suryani@yahoo.com
}

\begin{abstract}
This study aims to determine the effect of smartphone advertisements on consumer switching brand behavior in Bayung Lencir Subdistrict, Musi Banyuasin Regency. This research is a study of causality. The population of this study is consumers in the District of Bayung Lencir, especially those who use smartphones. The total sample of 100 people was determined using the Malhotra formula. The sample was selected using a purposive sampling technique. Data were collected using the questionnaire method and analyzed using simple linear regression analysis and correlation analysis. The results showed that (1) the correlation coefficient value of 0.844 showed that there was a very strong relationship or correlation between smartphone advertisements and consumer switching brand behavior in Bayung Lencir Subdistrict, Musi Banyuasin Regency, while the Adjusted $R$ Square value of 0.709 indicated that smartphone advertising affected behavior consumer brand switching is $70.9 \%$, (2) the results of the $t$ hypothesis test show that smartphone advertising significantly influences the brand switching behavior of consumers in the Bayung Lencir District of Musi Banyuasin Regency with a tcount $>$ ttable $(15,576>1,984)$.
\end{abstract}

Keywords:advertisements, smartphone, brand switching behavior

\section{PENDAHULUAN}

\section{Latar Belakang Masalah}

Pada dasarnya periklanan merupakan salah satu bentuk khusus komunikasi untuk memenuhi fungsi pemasaran. Periklanan harus mampu membujuk konsumen supaya berperilaku sedemikian rupa sesuai dengan strategi pemasaran perusahaan untuk mendapatkan penjualan dan keuntungan. Disamping itu periklanan juga dipandang sebagai salah satu media yang peling efektif di dalam mengkomunikasikan suatu produk barang atau jasa. Selain itu juga periklanan yang diluncurkan oleh setiap perusahaan tidak lain agar konsumen tertarik dan berharap tidak akan berpaling ke perusahaan sejenis. Dan untuk menciptakan hal tersebut dapat dengan cara menerapkan promosi periklanan yang menarik dan seefektif mungkin.

Periklanan adalah fenomena bisnis modern. Tidak ada perusahaan yang ingin maju dan memenangkan kompetisi bisnis tanpa mengandalkan iklan. Demikian penting peran iklan dalam bisnis modern sehingga salah satu bentuk bonafiditas perusahaan terletak pada seberapa besar dana yang dialokasikan untuk iklan tersebut. Di samping itu, iklan merupakan jendela kamar dari sebuah perusahaan. Keberadaannya menghubungkan perusahaan dengan masyarakat, khususnya para konsumen. Periklanan adalah bentuk komunikasi tidak langsung, yang didasari pada informasi tentang keunggulan atau keuntungan suatu produk, yangdisusun sedemikian rupa sehingga menimbulkan rasa 
menyenangkan yang akan mengubah pikiran seseorang untuk melakukan pembelian (Tjiptono, 2011:226).

Tingginya persaingan di pasar konsumen yang ditandai dengan banyaknya ragam pilihan produk baik barang maupun jasa yang ditawarkan oleh produsen memberikan kesempatan bagi konsumen untuk memilih merek produk yang dapat memenuhi serta memuaskan kebutuhan dan keinginan mereka. Beragam merek yang ditawarkan kepada konsumen memberikan kesempatan bagi konsumen untuk berpindah dari merek satu ke merek lainnya (brand switching). Kondisi ini menjadikan iklan sebagai suatu strategi yang sangat efektif untuk menguatkan pemahaman tentang produk di benak konsumen, karena iklan akan dengan mudah mempengaruhi persepsi konsumen terhadap suatu produk.

Pentingnya iklan bagi perusahaan dapat kita lihat dari pertumbuhan belanja iklan yang menunjukkan trend yang positif dari tahun ke tahun. Di Indonesia total belanja iklan tahun 2017 meningkat 8\% dari tahun sebelumnya dengan nilai yang mencapai Rp 145 Triliun. Pertumbuhan nilai ini lebih didorong oleh kenaikan harga gross rate iklan di masing-masing media. Demikian menurut hasil temuan Nielsen Ad Intel yang dirilis 1 Februari 2018 oleh Nielsen Indonesia. Porsi belanja iklan sepanjang 2017 masih didominasi oleh media TV sebesar $80 \%$ dari total belanja iklan yang tumbuh $12 \%$ dibandingkan tahun sebelumnya. Pertumbuhan yang sangat terlihat adalah dari sektor properti (62\%) dan kategori telekomunikasi dan digital (30\%) dengan total belanja iklan sepanjang tahun 2017 masing-masing mencapai Rp 4,1 Triliun dan Rp 13,3 Triliun.

Berdasarkan data tersebut di atas dapat dikatakan bahwa iklan merupakan kegiatan yang sangat penting bagi perusahaan karena iklan merupakan bagian dari pemasaran suatu produk (Tinarbuko, 2007:1). Iklan memang dapat mempengaruhi perilaku konsumen terhadap merek yang diiklankan. Pengaruh iklan pada perilaku konsumen ini sangat variatif, mulai dari mendorong konsumen untuk mencari produk yang dimaksud sampai dengan mendorong orang yang sebelumnya tidak loyal menjadi loyal.Berkaitan dengan pengaruh iklan terhadap perilaku konsumen, SurveyOne telah melakukan survei mengenai pengaruh iklan/promo terhadap keputusan konsumen dalam membeli merek/produk. Survei yang melibatkan 1.800 responden ini menunjukkan adanya pengaruh iklan terhadap keputusan konsumen dalam membeli merek/produk. Sebanyak 37,6\% responden menyatakan, pengaruh iklan dalam perilaku pembelian adalah besar dan sangat besar.

Perubahan perilaku pembelian konsumen sebagai akibat dari adanya pengaruh iklan pada akhirnya berdampak pada keputusan konsumen untuk mengalihkan pembelian dari satu merek produk ke merek produk lainnya (brand switching). Menurut Hawkins dan Mothersbaugh (2016:637), brand switching adalah Hasil ketidakpuasan konsumen akan suatu produk yang mengakibatkan konsumen melakukan penghentian pembelian produk pada suatu merek dan menggantinya dengan merek lain. Brand switching adalah perilaku konsumen yang mencerminkan pergantian dari merek produk yang biasa dikonsumsi dengan produk merek lain. Sementara menurut Assael dalam Kotler \& Armstrong (2007:202), dalam situasi pembelian yang ditandai keterlibatan konsumen yang rendah namun perbedaan merek yang signifikan, konsumen sering melakukan peralihan merek. Konsumen mungkin mengambil merek lain karena bosan atau ingin mencari rasa yang berbeda. Dengan demikian perpindahan merek terjadi selain karena adanya ketidakpuasan juga karena adanya keinginan mencari variasi.

Kebutuhan dan keinginan manusia yang sangat kompleks merupakan peluang bagi perusahaan untuk memasarkan produk. Manusia yang merupakan makhluk sosial memiliki kebutuhan salah satunya adalah kebutuhan dalam berkomunikasi. Seiring perkembangan zaman manusia semakin disibukkan dengan berbagai aktivitas yang mengakibatkan interaksi dengan manusia lainnya di satu sisi semakin intens dan di sisi lain semakin longgar. Sehingga manusia membutuhkan cara atau alat yang dapat 
memperlancar komunikasi dengan manusia lainnya. Alat komunikasi yang sampai saat ini selalu mengalami perkembangan dalam hal teknologi adalah telepon. Perkembangan telepon dimulai pada tahun 1876 yakni ketika telepon pertama kali ditemukan oleh Alexander Graham Bell.

Dengan adanya telepon kita dapat melakukan panggilan kemanapun dengan mudah dan instant; menghemat ruang dan waktu. Perkembangan telepon yang sangat pesat ditandai dengan adanya perbaikan serta inovasi yang dilakukan untuk mengembangkan telepon. Telepon yang pada awalnya hanya bisa dilakukan pada jarak dekat (beberapa $\mathrm{km}$ ) kini bisa dilakukan hingga lintas benua. Inovasi juga dilakukan pada sistem jaringan serta perangkat telepon itu sendiri. Gangguan-gangguan telepon sudah semakin diminimalisir, harga layanannya juga semakin murah, ukuran serta fungsi perangkat telepon pun semakin ringan dan canggih. Alat komunikasi canggih yang ada saat ini adalah telepon genggam (handphone) yang berbasis android yang dikenal dengan nama smartphone.

Smartphone adalah sebuah telepon genggam yang memiliki fitur atau kemampuan tingkat tinggi, sering kali dalam penggunaanya menyerupai komputer, sehingga banyak orang mengartikan smartphone sebagai komputer genggam yang memiliki fasilitas telepone. Fitur - fitur yang dapat ditemukan pada smartphone antara lain telepone, sms, internet, ebook viewer, editing dokumen dan masih banyak lagi yang lainnya. Kita juga dapat menambahkan aplikasi lain kedalam smartphone layaknya kita menginstall aplikasi pada komputer. Luasnya pemasaran smartphone hingga sampai ke berbagai pelosok daerah serta banyaknya peminat menunjukkan bahwa smartphone bukan lagi merupakan barang mewah. Dengan berbagai fitur yang ada pada smartphone, manfaat yang ditawarkan kepada konsumen benar-benar dapat memenuhi dan memuaskan kebutuhan dan keinginan konsumen.

Berdasarkan fenomena yang telah dikemukakan di atas, maka perlu untuk dilakukan penelitian di Kecamatan Bayung Lencir Kabupaten Musi Banyuasin, dengan unit analisis konsumen yang menggunakan smartphone. Adapun rumusan masalah dalam penelitian ini adalah: "Bagaimanakah pengaruh iklan smartphone terhadap perilaku brand switching konsumen Bayung Lencir Musi Banyuasin?”.

\section{Tujuan Penelitian}

Berdasarkan pada rumusan penelitian di atas, maka tujuan penelitian ini adalah untuk mengetahui pengaruh iklan smartphone terhadap perilaku brand switching konsumen Bayung Lencir Musi Banyuasin.

\section{KAJIAN PUSTAKA \\ Periklanan}

Tjiptono (2008:225-226) berpendapat bahwa agar dapat menarik konsumen untuk melakukan pembelian terhadap suatu produk, perusahaan harus melakukan kegiatan periklanan. Menurut Lee dan Johnson (2007: 3), periklanan adalah komunikasi komersil dan nonpersonal tentang sebuah organisasi dan produk-produknya yang ditransmisikan ke suatu khalayak target melalui media bersifat massal seperti televisi, radio, koran (surat kabar), majalah, direct mail (pengeposan langsung), reklame luar ruangan, atau kendaraan umum. Sedangkan menurut Kotler dan Armstrong (2010:125) iklan adalah segala bentuk presentasi nonpribadi dan promosi gagasan, barang dan jasa oleh sponsor tertentu yang harus dibayar.

Kotler (2007:601-603) mengelompokkan tujuan periklanan menjadi lima macam, yaitu: 
1. Periklanan Informatif (Informative Advertising)

Digunakan pada saat perusahaan memperkenalkan suatu produk baru, dimana tujuannya adalah membangun permintaan pokok atas kategori produk tersebut. Informative advertising jugamenginformasikan pada pasar yang dituju mengenai penawaran perusahaan. Promosi yang bersifat informasi umumnya dilakukan pada tahap awal siklus kehidupan produk.

2. Periklanan Persuasif (Persuasive Advertising)

Digunakan pada tahap persaingan dimana tujuannya membangun permintaan yang selektif akan merek produk. Iklan yang bersifat membujuk terutama diarahkan untuk mendorong pembelian. Iklan ini akan menjadi dominan jika produk tersebut mulai memasuki tahap pertumbuhan dalam siklus kehidupan produk. Disini perusahaan dapat membangun preferensi merek, berusaha agar konsumen beralih ke merek perusahaan, mempersuasi konsumen agar membeli sekarang juga serta mengubah persepsi konsumen terhadap atribut produk.

3. Pengingat Iklan (Reminder Advertising)

Iklan yang bersifat mengingatkan ini dilakukan terutama untuk mempertahankan merek poduk di hati masyarakat, fungsinya untuk mengingatkan konsumen untuk menggunakan produk tersebut.

4. Perbandingan Iklan (Comparison Advertising)

Pada jenis iklan ini, perusahaan berusaha untuk menciptakan superioritas merek dengan cara membandingkanya dengan merek lain dalam sebuah kelas produk. Dalam hal ini perusahan harus dapat membuktikan pernyataannya agar tidak dapat diserang balik olehmerek pesaingnya.

5. Penguat Iklan (Reinforcement Advertising)

Iklan ini berusaha meyakinkan konsumen bahwa mereka mengambil pilihan yang tepat. Tujuannya adalah mendorong konsumen untuk melakukan pembelian ulang. Iklan ini biasanya bersifat memberikan edukasi atau pendidikan kepada konsumen maupun pelanggan.

Suatu iklan menurut Tjiptono (2005:226-227) mempunyai sifat-sifat sebagai berikut:

\section{Public Presentation}

Iklan memungkinkan setiap orang menerima pesan yang sama tentang produk yang diiklankan.

2. Persuasiveness

Pesan iklan yang sama dapat diulang-ulang untuk memantapkan penerimaan informasi.

3. Amplifed Expresiveness

Iklan mampu mendramatisasi perusahaan dan produknya melalui gambar dan suara untuk menggugah dan mempengaruhi perasaan khalayak.

4. Impersonality

Iklan tidak bersifat memaksa khalayak untuk memperhatikan dan menanggapinya, karena merupakan komunikasi yang monolog (satu arah).

\section{Perancangan Pesan}

Dalam pembuatan suatu iklan, pesan iklan merupakan faktor yang penting. Menurut Chandra (2005:170), perancangan pesan berkaitan dengan empat isu utama, yaitu:

1) Isi pesan (massage content), yaitu menyangkut tiga macam daya tarik atau Unique Selling Preposition (USP) yang ditawarkan kepada para audiens yaitu: 
a) Daya tarik rasional, menekankan manfaat produk seperti kualitas, harga, value, atau kinerja.

b) Daya tarik emosional, berusaha memanfaatkan emosi positif seperti humor, cinta, rasa bangga, rasa senang atau memanfaatkan emosi negatif seperti rasa takut, rasa bersalah, malu, tegang, dan sedih.

c) Daya tarik moral, berfokus pada upaya mendorong konsumen agar mendukung dan berpartisipasi dalam berbagai aktivitas sosial.

2) Struktur pesan (massage structure), yaitu berkaitan dengan penarikan kesimpulan (conclusion drawing) dan urutan penyampaian pesan. Ada dua pilihan dalam hal penarikan kesimpulan, yakni membiarkan audiens menyimpulkan sendiri pesan yang dibaca/ditontonnya, atau perusahaan yang menegaskan kesimpulan untuk para audiens.

3) Format pesan (massage format), yaitu menyangkut headline, copy, ilustrasi dan warna (iklan media cetak); kata-kata, kualitas suara, dan vokalisasi (iklan di radio); kata-kata, warna, ilustrasi, kualitas suara, headlines, copy, dan body language (iklan di TV); tekstur, warna, ukuran, bentuk, dan aroma (produk atau kemasan).

4) Sumber pesan (massage source), terutama menyangkut kredibilitas penyampai pesan. Sumber pesan yang atraktif atau populer cenderung dapat menarik perhatian dan ingatan yang lebih besar dibanding orang awam.

\section{Perpindahan Merek (Brand Switching)}

Peter dan Olson (2014:522) mengungkapkan bahwa "Brand switching is purchasing patterns characterized by a change or shift from one brand to another brand". Perpindahan merek adalah pola pembelian yang dikarakteristikan dengan perubahan atau pergantian dari satu merek ke merek lainnya. Sedangkan menurut Hawkins dan Mothersbaugh (2016:637), brand switching adalah "Result of consumer dissatisfaction will result in a product that consumers make purchases cessation product to a brand and replace it with other brands". Hasil ketidakpuasan konsumen akan suatu produk yang mengakibatkan konsumen melakukan penghentian pembelian produk pada suatu merek dan menggantinya dengan merek lain.

Sehingga berdasarkan definisi tersebut dapat dijelaskan bahwa brand switching adalah saat dimana seorang pelanggan atau sekelompok pelanggan berpindah kesetiaan dari satu merek sebuah produk tertentu ke merek produk lainnya. Tingkat brand switching ini juga menunjukkan sejauhmana sebuah merek memiliki pelanggan yang loyal. Semakin tinggi tingkat brand switching, maka semakin tidak loyal pelanggan kita. Untuk itu berarti semakin beresiko juga merek yang kita kelola karena bisa dengan mudah dan cepat kehilangan pelanggan (Sumarni, 2010:56).

Van Trijp (1996) dalam Arianto dan Mulyani (2007:138) menyebutkan bahwa keputusan perpindahan merek dipengaruhi oleh faktor internal dan eksternal, dimana faktor internal terbagi menjadi keinginan mencari variasi, pengetahuan konsumen mengenai merek pada produk, dan ketidakpuasan. Sedangkan faktor eksternal terbagi lagi menjadi iklan, promosi dalam toko termasuk harga dan ketersediaan produk.

Menurut Schiffman dan Kanuk (2015:212), ada tiga tipe perpindahan merek (brand switching), yaitu

1. Explatory purchase behavior. Terdapat dua alasan konsumen dalam melakukan perpindahan merek, yaitu mendapatkan pengalaman baru dan kemungkinan memperoleh alternatif yang baik.

2. Vicarious exploration. Konsumen melakukan perpindahan merek karena informasi yang aman tentang sesuatu yang baru, alternatif yang berbeda ketika memikirkan atau mengingat sesuatu.

3. Use inovativeness. Konsumen melakukan perpindahan merek karena ingin lebih menggunakan produk yang mengalami pembaharuan. 
Shukla dalam Mutyalestari (2011:38) mengungkapkan bahwa hal-hal yang menjadi dasar pertimbangan dalam terjadinya brand switching adalah sebagai berikut:

1. Perceived quality (kualitas yang ditunjukkan)

Kualitas dari merek yang dimaksud disini tidak hanya sebatas pada pengepakan ataupun tingkat kecacatan produk yang rendah, namun harga yang bersaing dan pelayanan yang diberikan menjadi standar bahwa merek tersebut berkualitas.

2. Attractiveness of the product (daya tarik produk)

Setiap produk memiliki daya tarik masing-masing dimana ciri khas atas diferensiasi merek merupakan hal yang paling diunggulkan dalam meningkatkan daya tarik. Kreatifitas penawaran dipercaya sebagai alat ukur yang tepat dalam meningkatkan daya tarik produk.

3. Variety of features (variasi fitur)

Adalah berbagai macam elemen-elemen yang ditawarkan oleh sebuah produk. Semakin menarik fitur yang dimiliki oleh produk pesaing, maka semakin besar kemungkinan konsumen akan beralih menggunakan produk merek pesaing.

4. Commitment (komitmen pelanggan)

Adalah tingkat loyalitas konsumen ditengah berbagai macam rangsangan dari para pesaing sebelum melakukan perpindahan. Semakin rendah tingkat komitmen atau loyalitas pelanggan, maka semakin besar pula terjadinya perpindahan merek (brand switching).

\section{Penelitian Terdahulu}

Penelitian terdahulu digunakan oleh penulis sebagai acuan untuk menentukan beberapa hal yang berhubungan dengan teori dan sistematika penelitian ini antara lain:

1. Anggita Kurnia, Achmad Fauzi dan Dahlan Fanani (2016), dengan judul penelitian "Pengaruh Iklan Televisi terhadap Perpindahan Merek". Hasil analisis dan pembahasan menunjukkan bahwa berdasarkan hasil pengujian bersama-sama yang dapat dilihat pada tabel hasil uji $\mathrm{F}$, diperoleh nilai $\mathrm{F}$ hitung sebesar 26.440, sedangkan $\mathrm{F}$ tabel adalah sebesar 2,45 $(\mathrm{a}=0.05$; $\mathrm{df}$ regresi $=4$; $\mathrm{df}$ residual $=111) . \mathrm{F}$ hitung $>$ F tabel yaitu $26,440>2,45$ atau nilai Sig. $F(0,000)<\mathrm{a}=0.05$ maka model analisis regresi adalah signifikan. Hal ini berarti $\mathrm{H}_{0}$ ditolak dan $\mathrm{H}_{1}$ diterima sehingga dapat disimpulkan bahwa variabel isi pesan $\left(\mathrm{X}_{1}\right)$, struktur pesan $\left(\mathrm{X}_{2}\right)$, format pesan $\left(\mathrm{X}_{3}\right)$ dan sumber pesan $\left(\mathrm{X}_{4}\right)$ secara bersama-sama berpengaruh signifikan terhadap variabel perpindahan merek.

2. Budhi Ade Sulistyo dan Ida Maftukhah (2016), dengan judul penelitian "Analisis Pengaruh Perpindahan Merek Melalui Harga, Iklan, dan Ketidakpuasan Konsumen”. Hasil uji hipotesis membuktikan bahwa iklan berpengaruh positif dan signifikan terhadap perpindahan merek dengan nilai $t$ hitung sebesar 4,640 dan nilai signifikansi sebesar $0,000<0,05$.

3. Mia Lestari (2010), dengan judul penelitian "Analisis Faktor-faktor yang Mempengaruhi Perpindahan Merek (Brand Switching) pada Konsumen Biore Facial Foam (Facial Fit- Expert) (Studi Kasus pada Perempuan di Daerah Ciputat). Melalui analisis faktor telah terbentuk 7 (tujuh) faktor yang berpengaruh terhadap keputusan perpindahan merek (brand switching) yang dilakukan oleh konsumen facial foam Biore. Adapun faktor yang paling dominan dalam keputusan perpindahan merek (brand switching) pada konsumen perempuan Biore facial foam terdapat pada komponen pertama dengan totaleigen values sebesar 6,052. Dimana komponen terdiri dari lima variabel yaitu, faktor iklan yang bernilai dan sesuai harapan konsumen, iklan yang membangun keterkaitan elemen iklan dengan produk, pesan iklan yang mengaplikasikan kepribadian seseorang dan bernuansa kemanusiaan (human interest), iklan banyak menginformasikan tentang produk, dan daya tarik produk. 


\section{METODE PENELITIAN}

\section{Rancangan Penelitian}

Desain penelitian adalah kerangka atau cetak biru dalam melaksanakan suatu proyek riset, dimana didalamnya terperinci prosedur-prosedur yang diperlukan untuk memperoleh informasi yang dibutuhkan untuk menstruktur atau memecahkan masalahmasalah penelitian (Malhotra, 2004:87). Penelitian ini merupakan penelitian konklusif, yaitu penelitian yang didesain untuk membantu pembuat keputusan menentukan, mengevaluasi, dan memilih rangkaian tindakan terbaik untuk diambil dalam situasi yang ada. Jenis penelitian yang digunakan dalam penelitian konklusif ini adalah penelitian kausalitas. Menurut Sugiyono (2013:56) hubungan kausal adalah hubungan yang bersifat sebab akibat. Jadi disini ada variabel independen (variabel yang mempengaruhi) dan variabel dependen (dipengaruhi).

\section{Unit Analisis Penelitian}

Unit analisis adalah unit yang akan diteliti dan akan dijelaskan serta merupakan obyek penelitian yang dapat berupa individu, perorangan, kelompok, organisasi, masyarakat, hasil karya manusia, instansi dan sebagainya (Kusmayadi dan Sugiarto, 2000:73). Berkaitan dengan hal tersebut, unit analisis dalam penelitian ini adalah konsumen di Kecamatan Bayung Lencir Kabupaten Musi Banyuasin, sedangkan yang menjadi unit observasi adalah konsumen yang menggunakan smartphone.

\section{Populasi, Sampel dan Teknik Sampling}

Menurut Sugiyono (2013:90-91) bahwa yang dimaksud dengan populasi adalah wilayah generalisasi yang terdiri atas: objek/subjek yang mempunyai kualitas dan karakteristik tertentu yang ditetapkan oleh peneliti untuk dipelajari dan kemudian ditarik kesimpulannya. Sedangkan sampel adalah bagian dari jumlah dan karakteristik yang dimiliki oleh populasi tersebut. Populasi dalam penelitian ini adalah konsumen di Kecamatan Bayung Lencir terutama mereka yang menggunakan smartphone. Ukuran sampel diambil dengan menggunakan rumus Hair et.al. Rumus Hair et.al. digunakan karena ukuran populasi yang belum diketahui dengan pasti. Hair et.al. (2010:176) menyarankan bahwa ukuran sampel minimum adalah 5-10 observasi untuk setiap parameter yang diestimasi. Jadi, dengan jumlah indikator sebanyak 20 dikalikan dengan 5 , didapat jumlah sampel sebanyak 100 orang.

Teknik pengambilan sampel yang digunakan dalam penelitian ini adalah teknik nonprobability sampling. Teknik nonprobability sampling adalah teknik pengambilan sampel yang tidak memberi peluang atau kesempatan yang sama bagi setiap unsur atau anggotapopulasi untuk dipilih menjadisampel (Sugiyono, 2013:95). Teknik nonprobability sampling yang digunakan dalam pengambilan sampel pada penelitian ini yaitu teknik purposive sampling. Teknik purposive sampling adalah adalah teknik penentuan sampel dengan pertimbangan tertentu (Sugiyono, 2013:96).

\section{Variabel Penelitian}

\section{a. Identifikasi Variabel}

Variabel-variabel yang dianalisis dalam penelitian ini meliputi variabel bebas (variabel independen) yaitu variabel $\mathrm{X}$ dan variabel terikat (variabel dependen) yaitu variabel Y. Menurut Sugiyono (2013:39), variabel independen adalah variabel yang mempengaruhi atau menjadi sebab perubahannya atau timbulnya variabel terikat. Sedangkan variabel dependen adalah variabel yang dipengaruhi atau yang menjadi akibatkarena adanya variabel independen. Variabel $\mathrm{X}$ dalam penelitian ini adalah iklan dan variabel $\mathrm{Y}$ adalah perilaku brand switching. Variabel-variabel tersebut diformulasikan sebagai berikut: 


$$
\mathbf{Y}=\mathbf{a}+\mathbf{b} X_{1}+\mathbf{e}
$$

dimana :

$$
\begin{array}{ll}
\mathbf{Y} & =\text { Brand switching } \\
\mathbf{X}_{1} & =\text { Iklan } \\
\mathbf{a} & =\text { Konstanta } \\
\mathbf{e} & =\text { error term }
\end{array}
$$

\begin{tabular}{|c|c|c|}
\hline Konsep Variabel & Dimensi & Indikator \\
\hline \multirow{4}{*}{$\begin{array}{l}\text { Iklan (X) adalah segala bentuk } \\
\text { presentasi non-pribadi dan } \\
\text { promosi gagasan, barang dan } \\
\text { jasa oleh sponsor tertentu yang } \\
\text { harus dibayar (Kotler dan } \\
\text { Armstrong, 2010:125) }\end{array}$} & Isi Pesan & $\begin{array}{ll}- & \text { Daya tarik rasional } \\
\text { - } & \text { Daya tarik emosional } \\
\text { - } & \text { Daya tarik moral } \\
\end{array}$ \\
\hline & Struktur Pesan & \begin{tabular}{llr} 
- & \multicolumn{2}{l}{ Efektivitas media yang } \\
& digunakan \\
- & Persepsi konsumen \\
& mengenai r produk \\
& setelah & iklan \\
& ditampilkan & \\
- & Kejelasan pesan
\end{tabular} \\
\hline & Format Pesan & $\begin{array}{ll}\text { - } & \text { Pesan yang disampaikan } \\
\text { dalam iklan } \\
\text { - } & \text { Frekuensi penayangan } \\
& \text { iklan } \\
\text { - } & \text { Visualisasi iklan } \\
\end{array}$ \\
\hline & Sumber Pesan & 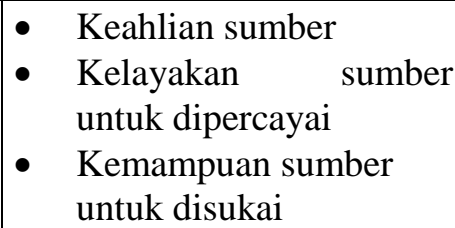 \\
\hline \multirow{4}{*}{$\begin{array}{l}\text { Brand switching (Y) adalah } \\
\text { pola pembelian yang } \\
\text { dikarakteristikan dengan } \\
\text { perubahan atau pergantian dari } \\
\text { satu merek ke merek lainnya } \\
\text { (Peter dan Olson, 2014:522) }\end{array}$} & $\begin{array}{c}\text { Kualitas yang } \\
\text { ditunjukkan }\end{array}$ & $\begin{array}{ll}\text { - } & \text { Produk tidak sulit untuk } \\
\text { direparasi } \\
\text { - } & \text { Kemudahan } \\
& \text { memperoleh sparepart }\end{array}$ \\
\hline & Daya tarik produk & $\begin{array}{ll}\text { - } & \text { Memiliki banyak } \\
\text { pilihan bentuk/tipe/seri } \\
\text { - } & \begin{array}{l}\text { Ditawarkan dengan } \\
\text { harga lebih bersaing }\end{array}\end{array}$ \\
\hline & Variasi fitur & $\begin{array}{ll}- & \text { Fitur yang lengkap } \\
- & \text { Kesesuaian fitur dengan } \\
\text { kebutuhan dan } \\
\text { keinginan pelanggan }\end{array}$ \\
\hline & Komitmen pelanggan & $\begin{array}{l}\text { - Selalu memilih merek } \\
\text { yang sama } \\
\text { - Memberikan referensi }\end{array}$ \\
\hline
\end{tabular}

\section{b. Operasionalisasi Variabel}

Tabel 1.

Operasionalisasi Variabel 


\begin{tabular}{|l|l|l|}
\hline & & kepada pihak lain \\
\hline
\end{tabular}

\section{Pengukuran Variabel}

Indikator-indikator dari masing-masing variabel dalam penelitian ini akan diukur dengan menggunakan Skala Likert. Menurut Sugiyono (2013:132), skala Likert digunakan untuk mengukur sikap, pendapat dan persepsi seseorang atau sekelompok orang tentang fenomena sosial. Adapun kriteria penilaian yang digunakan berupa: (1) Sangat Tidak Setuju (STS), (2) Tidak Setuju (TS), (3) Netral (N), (4) Setuju (S), dan (5) Sangat Setuju (SS).

\section{Instrumen Penelitian}

\section{a. Kuesioner}

Instrumen penelitian adalah suatu alat yang digunakan untuk mengukur fenomena alam maupun sosial yang diamati (Sugiyono, 2013:146). Adapun instrumen yang digunakan dalam penelitian ini adalah kuesioner. Kuesioner merupakan teknik pengumpulan data yang dilakukan dengan cara memberi seperangkat pertanyaan atau pernyataan tertulis kepada responden untuk dijawab (Sugiyono, 2013:199).

\section{b. Uji Validitas}

Uji validitas adalah untuk mengetahui tingkat kevalidan dari kuesioner yang digunakan dalam pengumpulan data. Menurut Arikunto (2013:85), agar dapat memperoleh data yang valid, maka instrumen atau alat untuk mengevaluasi harus valid. Sedangkan menurut Sugiyono (2013:173), valid berarti instrumen tersebut dapat digunakan untuk mengukur apa yang seharusnya diukur.

\section{c. Uji Reliabilitas}

Arikunto (2013:100) mengemukakan bahwa reliabilitas berhubungan dengan masalah kepercayaan. Uji reliabilitas artinya adalah tingkat keterpercayaan hasil suatu pengukuran. Pengukuran yang memiliki reliabilitas tinggi, yaitu pengukuran yang mampu memberikan hasil ukur yang terpercaya (reliabel). Reliabilitas merupakan salah satu ciri atau karakter utama intrumen pengukuran yang baik. Kadang-kadang reliabilitas disebut juga sebagai keterpercayaan, keterandalan, keajegan, konsistensi, kestabilan, dan sebagainya, namun ide pokok dalam konsep reliabilitas adalah sejauh mana hasil suatu pengukuran dapat dipercaya, artinya sejauh mana skor hasil pengukuran terbebas dari kekeliruan pengukuran (measurement error).

\section{Teknik Analisis Data}

\section{a. Analisis Regresi Linier Sederhana}

Analisis regresi merupakan salah satu metode statistika yang digunakan untuk menjelaskan hubungan fungsional antara variabel yang dinyatakan dalam suatu model atau persamaan. Model regresi sebagai alat untuk menerangkan, memahami, mengendalikan, dan memprediksikan hubungan antara variabel yang diteliti.

\section{b. Analisis Korelasi}

Analisis korelasi adalah metode statistik yang digunakan untuk mengukur besarnya hubungan linier antara dua variabel atau lebih. Jika korelasi bernilai positif maka hubungan antara dua variabel bersifat searah. Sebaliknya jika korelasi bernilai negatif maka hubungan antara dua variabel bersifat berlawanan arah.

\section{c. Koefisien Determinasi (Uji $\left.\mathbf{R}^{2}\right)$}


Uji $\mathrm{R}^{2}$ atau uji determinasi merupakan suatu ukuran yang penting dalam regresi, karena dapat menginformasikan baik atau tidaknya model regresi yang terestimasi. Nilai koefisien determinasi $\left(\mathrm{R}^{2}\right)$ ini mencerminkan seberapa besar variasi dari variabel terikat $Y$ dapat diterangkan oleh variabel bebas $X$. Bila nilai koefisien determinasi sama dengan 0 $\left(\mathrm{R}^{2}=0\right)$, artinya variasi dari $\mathrm{Y}$ tidak dapat diterangkan oleh $\mathrm{X}$ sama sekali. Sementara bila $\mathrm{R}^{2}=1$, artinya variasi dari $\mathrm{Y}$ secara keseluruhan dapat diterangkan oleh $\mathrm{X}$. Dengan kata lain bila $\mathrm{R}^{2}=1$, maka semua titik pengamatan berada tepat pada garis regresi. Dengan demikian baik atau buruknya suatu persamaan regresi ditentukan oleh $\mathrm{R}^{2}$ nya yang mempunyai nilai antara nol dan satu.

\section{d. Uji Hipotesis (Uji t)}

Uji t digunakan untuk menguji secara parsial masing-masing variabel. Hasil uji t dapat dilihat pada tabel coefficients pada kolom sig (significance). Jika probabilitas nilai $\mathrm{t}$ atau signifikansi $<0,05$, maka dapat dikatakan bahwa terdapat pengaruh antara variabel bebas terhadap variabel terikat secara parsial.

\section{HASIL DAN PEMBAHASAN}

\section{Analisis Regresi Linier Sederhana}

Analisis regresi linier berganda dilakukan ketika terdapat dua atau lebih variabel independen $(\mathrm{X})$ yang berpengaruh terhadap variabel dependen $(\mathrm{Y})$. Berdasarkan analisis regresi linier sederhana pengaruh iklan smartphone terhadap perilaku brand switching konsumen di Kecamatan Bayung Lencir, maka diperoleh hasil sebagai berikut:

Tabel 2.

\section{Hasil Analisis Regresi Linier Sederhana}

Coefficients

\begin{tabular}{|ll|r|r|r|r|r|}
\hline \multirow{2}{*}{ Model } & \multicolumn{2}{|c|}{$\begin{array}{c}\text { Unstandardized } \\
\text { Coefficients }\end{array}$} & \multicolumn{2}{c|}{$\begin{array}{c}\text { Standardized } \\
\text { Coefficients }\end{array}$} & & \\
\cline { 3 - 5 } & & \multicolumn{1}{|c|}{$\mathrm{B}$} & Std. Error & \multicolumn{1}{|c|}{ Beta } & \multicolumn{1}{c|}{$\mathrm{t}$} & \multicolumn{1}{c|}{ Sig. } \\
\hline 1 & (Constant) & 4,353 & 1,605 & & 2,711 &, 008 \\
& Iklan &, 579 &, 037 &, 844 & 15,576 &, 000 \\
\hline
\end{tabular}

a. Dependent Variable: Brand Switching

Berdasarkan hasil analisis regresi linier pada tabel 2 diatas, persamaan regresi yang dibentuk adalah: $\mathrm{Y}=4,353+0,579 \mathrm{X}+\mathrm{e}$. Persamaan regresi linier tersebut menggambarkan bahwa:

a. Nilai konstanta sebesar 4,353; artinya jika variabel iklan smartphone adalah nol, maka perilaku brand switching konsumen (Y) adalah sebesar 4,353.

b. Variabel iklan (X) mempunyai nilai koefisien regresi sebesar 0,579 yang berarti iklan smartphone mempunyai pengaruh positif terhadap perilaku brand switching konsumen. Dengan kata lain jika iklan smartphone ditingkatkan 1 satuan maka perilaku brand switching konsumen akan bertambah sebesar 0,579.

\section{Analisis Korelasi}

Tabel 3.

Hasil Analisis Korelasi

Model Summary

\begin{tabular}{|l|r|r|r|r|}
\hline Model & $\mathrm{R}$ & $\mathrm{R}$ Square & $\begin{array}{c}\text { Adjusted } \\
\mathrm{R} \text { Square }\end{array}$ & $\begin{array}{r}\text { Std. Error of } \\
\text { the Estimate }\end{array}$ \\
\hline 1 &, $844^{\mathrm{a}}$ &, 712 &, 709 & 2,54256 \\
\hline
\end{tabular}

Desemi

a. Predictors: (Constant), Iklan 
Tabel 3. di atas menunjukkan bahwa koefisien korelasi (R) adalah sebesar 0,844. Hal ini berarti hubungan antara iklan smartphone dengan perilaku brand switching konsumen bersifat signifikan karena nilai koefisien korelasi (R) mendekati 1.

\section{Koefisien Determinasi}

Tabel 3. juga memperlihatkan nilai koefisien determinasi (R Square) yang digunakan untuk mengetahui persentase pengaruh variabel independen $(\mathrm{X})$ terhadap variabel dependen (Y). Nilai Adjusted $R$ Square sebesar 0,709 menunjukkann bahwa perilaku brand switching konsumen dipengaruhi oleh variabel iklan smartphone sebesar $70,9 \%$, sedangkan sisanya sebesar $29,1 \%$ dipenaruhi oleh faktor-faktor lain yang tidak diteliti.

\section{Uji Hipotesis (Uji t)}

Untuk uji signifikansi pengaruh iklan smartphone terhadap perilaku brand switching konsumen di Kecamatan Bayung Lencir digunakan uji t atau uji parsial. Sampel yang digunakan sebanyak 100 orang, sehingga pengujian menggunakan uji $\mathrm{t}$ dengan $\mathrm{df}=$ 98 dan tingkat signifikansi $(\alpha)=5 \%$, maka diperoleh $\mathrm{T}_{\text {tabel }}$ sebesar 1,984. Dengan kriteria pengujian:

- Jika $T_{\text {hitung }}>T_{\text {tabel }}$, maka variabel $X$ mempunyai hubungan yang erat dan signifikan dengan variabel $\mathrm{Y}$.

- Jika $T_{\text {hitung }}<T_{\text {tabel}}$, maka variabel $X$ tidak mempunyai hubungan yang erat dan signifikan dengan variabel Y.

Berdasarkan pada tabel 2 dapat dilihat bahwa $\mathrm{T}_{\text {hitung }}$ untuk variabel iklan smartphone sebesar 15,576 lebih besar dari $\mathrm{T}_{\text {tabel }}$ sebesar 1,984. Sehingga dapat disimpulkan bahwa terdapat pengaruh iklan smartphone terhadap perilaku brand switching konsumen.

\section{Pembahasan Hasil Penelitian}

Melalui uji analisis regresi, analisis korelasi, uji koefisien determinasi, serta uji hipotesis, diperoleh hasil bahwa iklan smartphone berpengaruh terhadap perilaku brand switching konsumen di Kecamatan Bayung Lencir. Dalam penelitian yang dilakukan oleh penulis ditemukan bahwa variabel iklan smartphone yang diwakili oleh indikator isi pesan, struktur pesan, format pesan, dan sumber pesan mempunyai nilai koefisien regresi sebesar 0,579 yang berarti iklan smartphone mempunyai pengaruh positif terhadap perilaku brand switching konsumen di Kecamatan Bayung Lencir. Begitu juga hasil uji hipotesis (uji t) menunjukkan $\mathrm{T}_{\text {hitung }}$ untuk variabel iklan smartphone sebesar 15,576 lebih besar dari $\mathrm{T}_{\text {tabel }}$ sebesar 1,984. Ini berarti $\mathrm{H}_{1}$ diterima dan $\mathrm{H}_{0}$ ditolak.

Hasil penelitian ini sejalan dengan hasil penelitian yang dilakukan oleh Anggita Kurnia, Achmad Fauzi dan Dahlan Fanani (2016) tentang pengaruh iklan televisi terhadap perpindahan merek. Penelitian Anggita Kurnia, Achmad Fauzi dan Dahlan Fanani tersebut menunjukkan hasil bahwa iklan televisi yang diwakili indikator isi pesan, struktur pesan, format pesan, dan sumber pesan berpengaruh signifikan terhadap perpindahan merek dengannilai $F_{\text {hitung }}$ sebesar 26.440, sedangkan $F_{\text {tabel }}$ adalah sebesar 2,45. Begitu juga dengan penelitian yang dilakukan oleh Budhi Ade Sulistyo dan Ida Maftukhah (2016) tentang pengaruh perpindahan merek melalui harga, iklan, dan ketidakpuasan konsumen, dimana variabel iklan memiliki nilai $T_{\text {hitung }}$ sebesar 4,640 dan nilai signifikansi sebesar $0,000<0,05$. 
Dalam hal ini, Van Trijp (1996) dalam Arianto dan Mulyani (2007:138) menyebutkan juga bahwa keputusan perpindahan merek dipengaruhi oleh faktor internal dan eksternal, dimana faktor internal terbagi menjadi keinginan mencari variasi, pengetahuan konsumen mengenai merek pada produk, dan ketidakpuasan. Sedangkan faktor eksternal terbagi lagi menjadi iklan, promosi dalam toko termasuk harga dan ketersediaan produk.

\section{SIMPULAN DAN SARAN SIMPULAN}

Berdasarkan hasil uji analisis regresi linier sederhana dapat ditarik kesimpulan bahwa variabel iklan smartphone $(\mathrm{X})$ mempunyai pengaruh yang signifikan terhadap perilaku brand switching (Y) konsumen di Kecamatan Bayung Lencir. Dimana variabel iklan (X) mempunyai nilai koefisien regresi sebesar 0,579. Sedangkan hasil uji analisis korelasi menunjukkan bahwa koefisien korelasi (R) adalah sebesar 0,844 . Hal ini berarti hubungan variabel iklan smartphone dengan perilaku brand switching konsumen bersifat signifikan karena nilai koefisien korelasi (R) mendekati 1 . Sementara hasil uji t menunjukkan bahwa $\mathrm{T}_{\text {hitung }}$ untuk variabel iklan sebesar 15,576 lebih besar dari $\mathrm{T}_{\text {tabel }}$ sebesar 3,182. Sehingga dapat disimpulkan bahwa terdapat pengaruh iklan smartphone terhadap perilaku brand switching konsumen di Kecamatan Bayung Lencir.

\section{SARAN}

Mengacu pada simpulan tersebut diharapkan kepada para vendor produk smartphone untuk tidak hanya menciptakan produk yang berkualitas dengan segala kelebihan yang dimilikinya. Para vendor produk smartphone juga perlu meningkatkan ketajaman kreativitas dalam mempromosikan produk sehingga dapat lebih mudah dalam mempengaruhi persepsi konsumen, terutama untuk dapat mempertahankan loyalitas pelanggan terhadap produk.

\section{DAFTAR PUSTAKA}

Arianto, Dwi Agung Nugroho dan Sri Mulyani. 2007. Pengaruh Lingkungan Internal, Lingkungan Eksternal, Respon Emosional dan Respon Rasional terhadap Perpindahan Merek (Studi pada Remaja Konsumen Sabun Mandi di Swalayan Saudara Jepara). Jurnal Dinamika Ekonomi dan Bisnis, Vol. 4, No. 2, Tahun 2007.

Arikunto, Suharsimi. 2013. Prosedur Penelitian: Suatu Pendekatan Praktik. Jakarta: Rineka Cipta.

Chandra, Gregorius. 2005. Strategi Pemasaran. Yogyakarta: Andi

Hawkins, Delbert dan David Mothersbaugh. 2016. Consumer Behaviour. 13th Edition. McGraw-Hill.

Kotler, Philip. 2007. Manajemen Pemasaran. Jakarta: Indeks.

Kotler, Philip dan Gary Armstrong. 2010. Prinsip-prinsip Pemasaran. Jakarta: Erlangga.

Kusmayadi dan Endar Sugiarto. 2000. Metodologi Penelitian dalam Bidang Kepariwisataan. Jakarta: Gramedia Pustaka Utama. 
Kurnia, Anggita, Achmad Fauzi dan Dahlan Fanani. 2016. Pengaruh Iklan Televisi terhadap Perpindahan Merek (Survei pada Mahasiswa Angkatan 2012/2013 Jurusan Administrasi Bisnis, Fakultas Ilmu Administrasi Universitas Brawijaya). Jurnal Administrasi Bisnis (JAB), Vol. 29, No. 1, Desember 2015.

Lee, Monle dan Carla Johnson. 2007. Prinsip-prinsip Periklanan dalam Perspektif Global. Jakarta: Kencana Prenada Media.

Malhotra, Naresh K. 2004. Marketing Research: An Applied Orientation. Fifth Edition. Pearson Education, Inc. New Jersey.

Mutyalestari, Akari. 2009. Pengaruh Emotional Branding terhadap Perilaku Brand Switching Konsumen. Jurnal Bisnis dan Manajemen Fakultas Ekonomi Universitas Padjajaran Bandung.

Peter, J Paul dan Jerry C. Olson. 2014. Perilaku Konsumen dan Strategi Pemasaran. Jakarta: Salemba Empat.

Schiffman, Leon G dan Leslie Lazar Kanuk. 2015. Consumer Behavior. 10th Edition. Boston: Pearson Education.

Sugiyono. 2013. Metode Penelitian. Bandung: Alfabeta.

Sulistyo, Budhi Ade dan Ida Maftukhah. 2016. Analisis Pengaruh Perpindahan Merek Melalui Harga, Iklan, dan Ketidakpuasan Konsumen. Management Analysis Journal, Vol. 5, No. 2, Tahun 2016. ISSN 2252-6552.

Tinarbuko, Sumbo. 2007. Semiotika Iklan Sosial. Yogyakarta: Jalasutra.

Tjiptono, Fandy. 2011. Strategi Pemasaran. Edisi 3. Yogyakarta: Andi 